\title{
Engineering the Follicle Microenvironment
}

\author{
Erin R. West, M.S.E. ${ }^{1}$, Lonnie D. Shea, Ph.D. ${ }^{1,2,3}$, and Teresa K. Woodruff, Ph.D. $2,3,4$ \\ 1Department of Chemical and Biological Engineering, Northwestern University, Evanston, Illinois
}

2Center for Reproductive Research, Northwestern University, Evanston, Illinois

3The Robert H. Lurie Comprehensive Cancer Center of Northwestern University, Chicago, Illinois

4Department of Obstetrics and Gynecology, The Feinberg School of Medicine, Northwestern University, Chicago, Illinois

\begin{abstract}
In vitro ovarian follicle culture provides a tool to investigate folliculogenesis, and may one day provide women with fertility-preservation options. The application of tissue engineering principles to ovarian follicle maturation may enable the creation of controllable microenvironments that will coordinate the growth of the multiple cellular compartments within the follicle. Three-dimensional culture systems can preserve follicle architecture, thereby maintaining critical cell-cell and cellmatrix signaling lost in traditional two-dimensional attached follicle culture systems. Maintaining the follicular structure while manipulating the biochemical and mechanical environment will enable the development of controllable systems to investigate the fundamental biological principles underlying follicle maturation. This review describes recent advances in ovarian follicle culture, and highlights the tissue engineering principles that may be applied to follicle culture, with the ultimate objective of germline preservation for females facing premature infertility.
\end{abstract}

\section{Keywords}

Follicle; ovary; biomaterials; alginate; tissue engineering

The ovary is composed of follicles: specialized reproductive units that support the development of the mature gamete. Each follicle varies in its fate, and the factors regulating follicle growth, death, and recruitment largely remain a mystery. In vitro follicle culture systems have facilitated research into the regulation of follicle development, ${ }^{1-6}$ leading to improved understanding of reproductive function, disease, and potential therapeutic treatments for reproductive disorders. Recent applications of tissue engineering technologies to follicle culture have yielded novel systems that maintain follicle structure and improve follicle health in vitro. ${ }^{7-9}$ Developments in the field of tissue engineering have produced numerous technologies and tools that may further enable the engineering of follicle culture systems to better mimic the environment of the ovary, thereby improving follicle health in vitro.

In vitro follicle culture techniques provide a useful model in which to study folliculogenesis, and may also provide a means to preserve reproductive potential for females facing premature infertility due to cancer therapies. Currently, the only widely accepted method to preserve fertility for these women is via embryo cryopreservation. Unfortunately, this is not a viable

Address for correspondence and reprint requests: Teresa K. Woodruff, Ph.D., Department of Obstetrics and Gynecology, The Feinberg School of Medicine, Northwestern University, Chicago, IL 60611. E-mail: tkw @ northwestern.edu..

Genetics of Ovarian Failure and Development; Guest Editor, Aleksandar Rajkovic, M.D., Ph.D. 
option for adolescent and single women, as well as women who are unable to undergo an in vitro fertilization (IVF) cycle due to the nature of the cancer or the need for immediate treatment. Successful cryopreservation of ovarian tissue from these women enables the storage of this tissue until later in life. A successful in vitro culture system would then support the development of this immature tissue to produce mature follicles and oocytes, which could be subsequently fertilized to produce viable embryos.

The first isolated follicle culture was performed in 1977,10 and since this time much progress has been made in determining the proper in vitro conditions to support follicle development. Although existing in vitro culture models are well-suited to investigate the relationship between the microenvironment, cellular responses, and follicle maturation, these systems are still far from mimicking the natural environment of the ovary. The development of the ovarian follicle pool is a complex developmental process characterized by a dynamic interplay between ovarian cells and their environment. The coordinated activity of these stimuli functions to promote or inhibit follicle growth and atresia, and must be preserved in an in vitro system. Therefore, the in vitro environment must be tailored to provide follicles with the necessary signals present in the ovary, and must maintain the communication pathways within the follicle throughout development.

This review describes the development of follicle culture systems to date, and highlights the opportunities to apply tissue engineering technologies to follicle culture. We describe various biomaterials that may be useful in engineering novel culture systems, as well as techniques by which these materials may be manipulated to regulate the biochemical and mechanical environment surrounding the follicle.

\section{FOLLICULOGENESIS IN THE MAMMALIAN OVARY}

The ovarian follicle is the reproductive unit of the ovary, and consists of the oocyte and its associated somatic cells. The follicle pool within the ovary is composed primarily of dormant, primordial follicles, which contain an oocyte arrested at the diplotene stage of meiosis surrounded by a single layer of squamous somatic granulosa cells. Folliculogenesis begins as primordial follicles are gradually and continuously recruited to begin growth in a process which is not yet well understood. ${ }^{11}$ Upon recruitment, the oocyte grows and the granulosa cells become cuboidal, at which time the follicle is termed a primary follicle. At the primary stage, the follicle contains a basement membrane surrounding the follicle outside the granulosa cell layer, as well as a clear glycoprotein layer between the oocyte and granulosa cells, termed the zona pellucida. Following the primary stage, the oocyte continues to grow and the granulosa cells proliferate to form multiple layers surrounding the oocyte. The resulting follicle is termed a secondary follicle. At this time, theca cells begin to differentiate and surround the follicle outside the basement membrane. Following puberty and the onset of follicle-stimulating hormone (FSH) production, follicles grow beyond this secondary stage. Granulosa cells continue to proliferate, and also differentiate to form cumulus and mural granulosa cells, which surround the oocyte and the interior of the basement membrane, respectively. The theca cells also differentiate to form the theca interna (a vascularized layer of secretory cells) and the theca externa (an outer layer of connective tissue). This mature follicle is then termed an antral or Graafian follicle, and will rupture upon stimulation with luteinizing hormone (LH), releasing the oocyte into the pelvic cavity. Although many follicles are recruited to begin development, most degenerate during development in a process termed atresia, and only a small number of follicles reach the Graafian stage and undergo ovulation. ${ }^{11}$

Regulation of folliculogenesis is a complex and coordinated process. Follicle development is regulated by many endocrine and paracrine factors, $2,4,5$ as well as the extracellular matrix (ECM) of the follicle. ${ }^{12-16}$ Signaling between the oocyte and its neighboring granulosa cells 
has been shown to be essential to produce a mature, healthy oocyte, as well as for granulosa cell proliferation and differentiation. ${ }^{17-19}$ The compartments of the follicle are separated, however, by the basal lamina and zona pellucida, which limit direct contact between ovarian cells. Bidirectional methods of communication must therefore exist ${ }^{2,17,20-22}$ to allow for the exchange of these chemical factors. Specifically, gap junctions between granulosa cells and between granulosa cells and the oocyte allow for direct transport of factors between these cell types (Figs. 1A and 1B). These interactions have been shown to establish polarity in the follicle, 23 and control oocyte development by transfer of metabolic substrates and meiosis-arresting signals. ${ }^{17,24-26}$ Soluble factors secreted by granulosa and theca cells allow for interactions between these cell types (Figs. 1B and 1C), and factors produced in the anterior pituitary (i.e., FSH and LH) arrive at the ovary via the circulatory system, where they regulate follicle development (Fig. 1D). Finally, the ECM composition surrounding each cell type has been shown to regulate the function of these cells (Fig. 1E). Cell-cell and cell-matrix interactions play a vital role in coordinating follicle development, and must therefore be preserved to support physiological follicle development in vitro.

\section{DEVELOPMENT OF FOLLICLE CULTURE SYSTEMS}

The first successful attempt to grow ovarian tissue in vitro was performed by Martinovitch in 1937. ${ }^{27}$ In this study, whole mouse and rat ovaries were cultured on watch glasses in a primitive culture medium, and growth and differentiation of germ cells was observed in all cultures. Development of improved medium allowed for the first in-depth study of in vitro culture conditions by Eppig in $1977 .{ }^{10}$ In this study, Eppig determined that only oocytes that remained within follicles demonstrated significant growth, demonstrating that oocytes must remain in contact with granulosa cells to grow and mature. This landmark study was the first successful attempt to culture isolated follicles in vitro. Since the publication of these results, many attempts have been made to improve the follicle isolation procedure and in vitro culture conditions to support follicle and oocyte development. ${ }^{1-6}$

In vitro culture systems can generally be categorized into two approaches. ${ }^{1}$ The first is an attached follicle approach in which isolated follicles are placed on a two-dimensional surface and permitted to attach and spread on the surface. As illustrated in Figs. 2A and 2C, proliferating granulosa cells move away from the oocyte as they migrate onto the two-dimensional substrate. The second approach is the three-dimensional intact follicle approach, in which follicles do not adhere to a surface and therefore maintain their native architecture. As illustrated in Figs. 2B and 2D, increase in follicle size due to oocyte growth and granulosa cell proliferation occurs radially from the center of the follicle, as would follicle growth within the ovary. Although both approaches have produced live offspring $8,28,29$ and have provided useful insight into the process of folliculogenesis, three-dimensional approaches maintain the cell-cell and cellmatrix interactions, which are critical regulators of follicle development (Fig. 1).

\section{Two-Dimensional Follicle Culture Systems}

Two-dimensional attached follicle culture has been used to culture isolated follicles in a variety of studies. ${ }^{30-38}$ In such systems, isolated follicles are placed on a two-dimensional surface of either tissue culture plastic or surfaces coated with molecules such as collagen or polylysine. 39,40 The follicles attach to the surface and the proliferating granulosa cells break through the basement membrane and migrate onto the culture surface, resulting in a diffuse morphology, 30 as illustrated in Fig. 2A. Although these systems have proven successful in producing quality oocytes and live murine off-spring, 28,29 they have not been able to support normal follicle development in bovine, ${ }^{41}$ ovine, ${ }^{42}$ or human systems. ${ }^{43,44}$ Maintaining the associations between the oocyte and granulosa cells is more difficult in these large animal species because their follicles reach a much larger size and require a longer time in culture. ${ }^{6}$ This disruption of follicle architecture must be overcome to create a system for use in human fertility 
preservation, given that cell-cell and cell-matrix interactions play a role in follicle and oocyte development. ${ }^{17}$

\section{Three-Dimensional Follicle Culture Systems}

Three-dimensional culture of ovarian follicles maintains the morphology of the follicle and the cell-cell and cell-matrix interactions within the tissue. 7,45 Three-dimensional systems may also have an advantage in overcoming the difficulty of maintaining follicular structure for large species. ${ }^{3,6}$ In the case of human follicles, culture in a three-dimensional collagen gel promoted follicle growth, whereas follicles on a two-dimensional collagen-coated surface only maintained their original size. ${ }^{46}$ Approaches toward maintaining follicular architecture by preventing follicle adhesion include daily transferring of the follicle,, 7 use of membrane inserts, ${ }^{48}$ rotating walls and orbiting test tubes, ${ }^{49}$ inverted drops, ${ }^{50}$ or gel encapsulation. ${ }^{49}$, 51,52 Each of these culture systems is summarized in Table 1. Of these systems, most maintain three-dimensionality by limiting the access of follicles to an adhesive substrate, whereas two of the systems encapsulate the follicle in a three-dimensional matrix. In these latter two systems, the encapsulating matrix provides a defined substrate to the follicle in a three-dimensional geometry (Fig. 2B). The original report describing collagen encapsulation of follicles did not report oocyte quality, and no antral follicles were observed after 14 days of culture. ${ }^{51}$ No additional studies using this system have been reported. In the alginate system, however, follicles have been able to grow, 52 produce fluid-filled antral cavities, 9 and produce meiotically competent oocytes, 7,53 which were successfully fertilized and implanted to yield multiple live births of healthy mouse pups. ${ }^{8}$ Alginate has been widely studied as a matrix in a variety of tissue engineering applications, but investigation of the utility of alginate and other biomaterials in follicle culture is severely limited. The field of tissue engineering has yielded many new technologies that could be applied to three-dimensional follicle culture, which has the potential to yield a new generation of advanced culture systems.

\section{TISSUE ENGINEERING IN FOLLICLE CULTURE}

The growing field of tissue engineering combines cells, materials, and biological signals to repair, maintain, or enhance tissue function for regenerative and replacement therapies. ${ }^{54}$ Tissue engineering has revolutionized scientific understanding of the effects of an artificial environment on cellular function, and has produced novel technologies to direct tissue development. Each engineered tissue has different requirements for metabolism, growth factors, ECM, and mechanical characteristics. Engineers have developed novel techniques to meet these needs, which have many applications both in research and in clinical use for the repair and regeneration of damaged tissues.

Engineering the proper microenvironment to support ovarian follicle development in vitro is a task that presents unique challenges and opportunities. To date, little tissue engineering technology has been applied to follicle culture. As described previously, few attempts have been made to culture follicles in three-dimensional matrices. ${ }^{46,51,52}$ Providing controlled environments for follicle development can provide novel tools to investigate environmental factors that promote ovarian tissue development; little is understood about this application due to challenges in performing these studies in vivo. The development of an in vitro follicle culture system represents a unique opportunity in tissue engineering. Most tissues have an extensive vasculature that is required for providing nutrients and growth factors, and removing wastes. However, follicles are not vascularized inside of the theca layer and thus nutrients can be provided by simple diffusion in vitro. Most engineered tissues must be grown or eventually implanted in vivo, which produces the additional challenges of long-term biocompatibility, matrix degradation, vascularization, and integration with existing tissue. ${ }^{55}$ The clinical goal of in vitro follicle maturation is to produce a mature oocyte, which can then be fertilized and 
subsequently implanted. Therefore, a successful follicle culture system will not be hindered by implantation-related challenges.

When applying tissue engineering technologies to follicle culture, a variety of questions must be considered. First, what type of biomaterial will best suit the needs of the follicle? Second, what biochemical signals must be provided to the follicle, and what effect will the matrix have on the transport and presentation of these factors? Third, what are the mechanical needs of the follicle throughout development, and how can the matrix be manipulated to provide these properties? These questions are addressed in the subsequent sections.

\section{Biomaterials for Follicle Culture}

The first challenge in developing a follicle culture system is to determine the appropriate biomaterial for follicle encapsulation. Materials used in tissue engineering applications range from metals to ceramics to polymers, with the best material based on the specific requirements of each tissue. The ovary is a soft tissue, and the biomaterial used for culture must allow for expansion of the follicle. Naturally occurring polymers (such as collagen, fibrin, hyaluronic acid, and alginate), and synthetic polymers [such as polyethylene glycol (PEG), poly(lactic acid), and poly(glycolic acid)] have proven useful in tissue engineering applications. Advantages of natural materials include biocompatibility and bioactivity, whereas synthetic materials are advantageous due to the ease in control of mechanical and degradation properties, and offer versatility in designing an exogenous ECM with well-defined properties. ${ }^{55} \mathrm{~A}$ matrix for follicle culture must enable easy encapsulation with retention of viability, allow transport of nutrients and hormones toward and away from the follicle, permit follicle expansion, and provide for follicle collection at the end of culture. To investigate the role of specific factors of the microenvironment on follicle development, a material that can be readily manipulated to present a variety of mechanical and chemical signals is desirable.

CANDIDATE MATERIALS FOR FOLLICLE CULTURE SYSTEMS-Many potential materials are available that meet a majority of these requirements, including PEG, agarose, collagen, Matrigel (BD Biosciences, San Jose, CA), and alginate, for example. These materials are hydrogels, which provide a compliant matrix for follicle expansion. The properties of each of these potential materials are outlined in Table 2. Although the mechanical properties of PEG and agarose may be appropriate for follicle culture, the gelation and digestion options may harm the follicle during encapsulation. Ultraviolet light, harsh chemical agents, and high temperatures, which are used to crosslink the materials, have the potential to harm cells. In the case of PEG, a method for degradation would have to be developed to provide for follicle extraction at the end of culture, given that the cross-linking is not reversible. Collagen and Matrigel (solubilized basement membrane containing a variety of ECM proteins) possess increased potential as biomaterials for follicle culture. Their mechanical properties will allow for follicle expansion, and their innate bioactivity (via binding cell membrane integrins) may be beneficial to follicle culture. Unfortunately, the enzyme treatments required to extract follicles from these matrices will potentially digest the ECM within the follicle itself, thereby harming the follicle. In addition, the innate bioactivity of these materials limits the studies that may be performed to investigate the effects of extracellular factors on follicle development. Alginate is a promising material for use in follicle culture because of its gentle gelation and straightforward dissolution, which is discussed greater detail in the following section.

ALGINATE AS AN ENCAPSULATING MATRIX-Alginate, a naturally derived polymer produced by brown algae, has many characteristics of an ideal material for follicle culture. Alginate is a block copolymer of $\alpha$-L-guluronic acid $(G)$ and $\beta$-D-mannuronic acid $(M)$, and contains blocks of purely $\mathrm{G}$, purely $\mathrm{M}$, and alternating $\mathrm{G}$ and $\mathrm{M}$ monomers. ${ }^{56,57} \mathrm{In}$, the presence of calcium, the G-blocks of alginate crosslink, forming a hydrogel. Therefore, alginate 
does not require harsh chemical, light, or temperature treatments other gels may require (Table 2). In addition, alginate can be degraded by binding calcium with a chelator such as ethylene glycol bis( $\beta$-aminoethyl ether)-N,N,N',N'-tetraacetic acid (EGTA). However, calcium chelation can affect gap junctions and may adversely affect the follicle during retrieval. An alternative approach to removing the follicle is to degrade thealginate polymer with alginate lyase, an alginate-specific enzyme. Alginate has also been widely used for tissue engineering applications, ${ }^{58,59}$ and therefore many methods to manipulate the mechanical properties, 60-62 degradation, ${ }^{63}$ and biochemical activity ${ }^{62,64}$ (via coupling of bioactive molecules) have been developed. Alginate itself does not interact with integrins of mammalian cells, which allows for the introduction of well-defined signals (i.e., ECM proteins or peptides) for the study of the effects of specific ECM components on follicle development. Research has demonstrated that follicles encapsulated in alginate beads maintain their three-dimensional structure relative to two-dimensional culture systems (Fig. 2C and 2D). In addition, follicles cultured in alginate are able to produce fertilizable oocytes in an alginate matrix, ${ }^{52}$ and live mouse pups have been born using these follicles - the first live births produced using a three-dimensional culture system. ${ }^{8}$ The ability to tailor the matrix surrounding the follicle provides a well-defined environment in which the effects of specific ECM-integrin interactions on follicle development can be investigated.

\section{Biochemical Signals to Direct Follicle Development}

The signals necessary for follicle development must be presented within the context of the biomaterial. Both soluble and insoluble signals are known to regulate follicle development, 5 , 12,16 and must therefore be provided to the follicle in the proper form and dose. Soluble signals are generally easy to incorporate into in vitro systems because they can be added to culture media. The transport of these signals to the follicle is complicated, however, by the encapsulating matrix. The biomaterial surrounding the follicle may slow or prevent the transport of media factors to the follicle, and may also hinder the diffusion of waste products from the follicle. ${ }^{65,66}$ In addition to soluble factors, insoluble signals (i.e., ECM proteins) are present in the ovary, and may be necessary in the engineered matrix to direct follicle development. A variety of approaches have been taken to incorporate ECM components, including proteins and peptides, into engineered matrices. The presentation of the proper combination of biochemical signals to direct follicle development will improve follicle development in vitro.

SOLUBLE SIGNALS-Within the context of the ovary, the follicle receives soluble signals from ovarian cells as well as the blood supply. Autocrine and paracrine factors produced by ovarian cells diffuse away from the follicle in two-dimensional in vitro culture. Encapsulating cells in a three-dimensional matrix may limit the escape of these factors from the follicle microenvironment, thereby improving the effectiveness of these factors on the growing follicle. Factors arriving at the ovary via the blood supply must be added to culture medium for in vitro culture. Factors such as FSH, LH, and a variety of growth factors are known to regulate many aspects of follicle development, $1,4,5$ and may be necessary in in vitro systems. To successfully deliver soluble factors to encapsulated follicles, the size and chemical properties of the factors and the matrix must be considered. The pores or mesh size of the matrix must be sufficiently large to allow for the transport of these proteins from the culture media to the follicle. In addition, the factors may interact with the polymer backbone that comprises the hydrogel, inhibiting transport. These interactions are based on van der Waals, hydrophobic, and electrostatic interactions that could either repel the factors or promote adsorption to the matrix. Previous studies have demonstrated that the matrix type, concentration, and gelation treatments affect transport of molecules through the matrices. ${ }^{65,66}$ In the case of alginate, for example, varying the concentration of alginate (1.5 to $3 \%$ ) and the gelation time in a calcium chloride solution (1 to 5 minutes) significantly affects transport properties of large molecules (greater 
than $1300 \mathrm{Da}$ ). Transport of smaller molecules, which included oxygen, glucose, and vitamin $\mathrm{B}_{12}$, was not affected by changes to the alginate preparation. ${ }^{66}$ Matrix type also affected transport, given that molecules diffused through agarose gels more quickly than alginate gels. 66 The transport of these and other relevant growth factors must be examined in any engineered environment, as growth factors will be an important component of culture systems to investigate the independent and synergistic effects of such factors on follicle development.

INSOLUBLE SIGNALS-In addition to soluble signals, the ECM within the ovary is believed to regulate the function of follicular cells. ${ }^{12,14,16,67}$ The matrix within the ovary is diverse in composition and participates in follicle growth, corpora luteal development and regression, cell migration, division, specialization, differentiation, death, antrum development, oocyte maturation, and angiogenesis. ${ }^{12,68}$ The composition and function of the ovarian ECM is much less understood than that in other tissues, but recent and ongoing research is providing insight into this field. ${ }^{12,16,69-73}$

The role of the ECM for the in vitro culture of follicles is two-fold. First, the ECM regulates cellular function and differentiation within the follicle in vivo, and maintenance of the endogenous cell-ECM interactions in three-dimensional culture will facilitate ECM signaling in vitro. Several reports have begun to define the ECM within the follicle, and demonstrate the important role of ECM signaling throughout folliculogenesis (reviewed by Irving-Rodgers and Rodgers 12 and Rodgers et a ${ }^{16}$ ). Second, determining the necessary ECM components in the outer layers of the follicles will allow for the design of a bioengineered matrix containing exogenous ECM molecules. The isolation of follicles disrupts the cell-ECM interactions in the outer layers of follicular cells, and providing the proper ECM in an in vitro system may better support these cells, and therefore improve the quality of the follicle in culture.

ECM can be incorporated into tissue engineering scaffolds through multiple approaches. Natural materials, such as collagen and Matrigel, are themselves composed of ECM proteins and provide innate interactions with encapsulated cells. Other matrices, such as PEG and alginate, do not possess these innate interactions, and must be modified to mimic more effectively the ECM in vivo. Both intact proteins and small peptides have been coupled covalently to tissue engineering polymers to convey bioactivity in tissue engineering systems. 59,74-78 Peptides are advantageous because their small size allows for relatively straightforward chemical manipulation and tethering to biomaterials via chemical reaction. Whole proteins, however, better mimic the native ECM by presenting cells with multiple interactive peptide sequences, including binding and synergistic sites. In the case of follicle development, the incorporation of ECM proteins (collagen I and IV, fibronectin, and laminin) or the arginine-glycine-aspartic acid (RGD) peptide into an alginate matrix affected follicle growth and differentiation, as well as oocyte quality. ${ }^{7}$

\section{Matrix Mechanical Properties}

Although ECM signaling did influence follicle development, the mechanical properties of the three-dimensional matrix have been shown to have an even greater role in supporting follicle development. ${ }^{9}$ Mechanical stresses affect cell behavior in a variety of tissues, $, 9,80$ including those not typically considered to be mechanically challenged. ${ }^{81-85}$ Mechanotransduction is an important factor in regulating tissue development, but the molecular basis of this process has been investigated only recently, and much remains unknown. ${ }^{86-101}$ Potential mechanisms for mechanotransduction involve autocrine mechanoregulatory circuits or guanosine triphosphatase-dependent mechanisms, but many details remain to be determined. ${ }^{81,83,102}$ In the case of the follicle, the pressure exerted by the surrounding matrix may affect actin organization within the follicle, likely activating one or more of these mechanoresponsive pathways. In a three-dimensional system, cell-cell and cell-matrix interactions are maintained; 
therefore, a mechanical force applied to the cells at the exterior of the follicle will be transmitted to all cells within the follicle to influence development and maturation.

Variations in the mechanical properties of hydrogels regulate tissue formation in engineered tissues ${ }^{103-105}$ by directing cell survival, proliferation, differentiation, and migration rates. Interestingly, matrix elasticity regulates differentiation of stem cells, and in the long term, commit the cells to their respective lineages such that they are not reprogrammed by the addition of soluble induction factors. ${ }^{106}$ In this study, matrices mimicking the mechanical properties of brain, muscle, and bone were neurogenic, myogenic, and osteogenic, respectively. Many methods have been used to regulate the mechanical properties of polymer matrices, including the concentration of the polymer, the type and properties of their constitutive monomers, cross-link type and density, and the molecular weight of the polymer. In addition, manipulating the degradation rate of the hydrogel can enable a controlled reduction in the matrix elasticity. ${ }^{63}$ These techniques have produced matrices tailored for the specific mechanical needs of a variety of tissues.

In the case of the ovarian follicle, the matrix must have sufficient rigidity to maintain the threedimensional structure of the follicle, yet must also allow for expansion due to oocyte growth, granulosa cell proliferation, and antrum formation. Forces are generated by follicles in threedimensional matrices because the growing follicle exerts an outward force on its surrounding matrix, which is reciprocated by the surrounding matrix at a magnitude dependent upon the stiffness of the matrix and the force exerted by the follicle (Fig. 2B). The resulting increased pressure on the follicle may account for the apoptosis and/or the decreased proliferation rates of follicle cells in relatively incompliant matrices, as is the case in other tissues. ${ }^{82}$ Studies investigating the role of alginate consistency on follicle development have indicated that the environment surrounding the follicle can be defined as permissive and nonpermissive, based on the environments ability to regulate not only follicle development but also the behavior of individual cells of the follicle and the quality of the oocyte. ${ }^{9}$

Permissive three-dimensional matrices for follicle encapsulation support morphological changes during development, cellular differentiation, and enzymatic activity. ${ }^{9}$ In this study, follicles were cultured in alginate of varying density ( 0.25 to $1.5 \% \mathrm{w} / \mathrm{v})$ for a period of 12 days. Steroid levels were monitored during culture, and RNA was isolated for gene expression analysis. At the end of culture, oocytes were collected for fertilization, and fertilization rates and embryo development were assessed. In permissive (low density) matrices, follicles demonstrated increased granulosa and theca cell proliferation and differentiation, and demonstrated increased growth due to proliferation and antrum formation. In addition, oocytes from follicles cultured in $0.25 \%$ alginate demonstrated the highest rates of fertilization and blastocyst formation. Interestingly, the results of this study demonstrated the high degree of coordination between the follicle compartments, which occurs during follicle development in vitro. Specifically, luteinizing hormone/choriogonadotropin receptor (Lhcgr) gene expression was upregulated in $0.25 \%$ alginate matrices, which correlated with increased antrum formation, oocyte fertilization, and blastocyst formation rates. Androstenedione production also increased with decreasing alginate consistency, even though no LH was added to the system. Such results may demonstrate a change in the autocrine and paracrine factor regulation within the follicle in permissive culture environments. Taken together, the results from this study demonstrated that low-concentration alginate provides a more permissive environment for follicle development relative to higher concentration matrices. Determining the appropriate mechanical environment at each stage of follicle environment will be necessary to the development of a three-dimensional encapsulated follicle culture system. 


\section{FUTURE DIRECTIONS}

To date, in vitro follicle culture systems have facilitated research to better understand the complex process of folliculogenesis, and have demonstrated potential as a means of germline preservation. Follicle development is a dynamic process, and the field of tissue engineering has produced novel technologies that may be useful in engineering designer microenvironments to support and coordinate follicle development in vitro. Determining the ideal biomaterial, biochemical signals, and mechanical properties to support folliculogenesis will greatly improve the potential research and clinical applications of in vitro systems. Follicle culture holds promise in developing fertility-preserving therapies for cancer survivors, as well as for the in vitro study of folliculogenesis. Application of tissue engineering technologies to ovarian follicle maturation provides an opportunity to overcome this challenging endeavor.

Clinically, follicle culture systems may provide options for germline preservation for female cancer patients. Advances in cancer therapies have improved survival rates for patients, and current treatments can cure more than $90 \%$ of children and adolescents affected by cancer.

107 In fact, by 2010 it is estimated that one in 250 adults will be survivors of childhood cancers. 108 Unfortunately, these life-saving treatments often lead to infertility. Currently, the only widely accepted method for fertility preservation for females is via embryo cryopreservation. This avenue requires the female to be of reproductive age, have a male partner with whom they would like to have children, and be able to delay cancer treatment to complete an IVF cycle. For females unable to meet these criteria, options for fertility preservation are limited. ${ }^{3}$, 109-113 Avenues investigated have included cryopreservation of whole ovaries, ovarian cortical strips, whole follicles, or oocytes for later use by transplantation or in vitro development and fertilization. Transplantation of cryopreserved ovarian tissue in women has recently led to pregnancy and birth of healthy offspring, 114,115 but success has been limited. To date, the development of primordial follicles to produce fertilizable oocytes and live births has been achieved only in mice. $8,28,29$ Although attempts have been made in humans, they have yet to be successful. ${ }^{3}$ Improvements to in vitro follicle culture systems, along with improved cryopreservation 116 and follicle isolation ${ }^{117}$ techniques, may provide a viable avenue for the maturation of cryopreserved immature ovarian follicles in vitro for subsequent fertilization and implantation to preserve reproductive options for female cancer patients.

In addition to germline preservation, follicle culture techniques may also revolutionize approaches to treat female infertility. Current methods such as IVF require ovulation induction therapy. These hormonal treatments may lead to ovarian hyperstimulation syndrome, a potentially life-threatening disorder. ${ }^{118}$ In addition, ovulation induction produces a limited number of oocytes, many of which may not produce viable embryos. In vitro culture systems may allow for the maturation of immature follicles for subsequent oocyte collection and fertilization. If a viable human in vitro follicle culture system is developed, a small portion of the ovary could be removed laparoscopically, and follicles could be cultured and observed to yield fertilizable germ cells. This approach may also potentially allow women to delay childbearing until later in life due to lifestyle or other reasons.

In vitro follicle culture systems have many potential clinical and research applications, but improvements to current technologies are needed to make these applications a reality. The application of tissue engineering techniques to follicle culture have already led to improvements to culture system technologies, and further improvements may one day produce culture systems capable of producing successfully maturing human ovarian follicles.

\section{ACKNOWLEDGMENTS}

Funding for this work was provided by National Institutes of Health grant U54 HD41857. 


\section{REFERENCES}

1. Nayudu PL, Fehrenbach A, Kiesel P, et al. Progress toward understanding follicle development in vitro: appearances are not deceiving. Arch Med Res 2001;32:587-594. [PubMed: 11750734]

2. Senbon S, Hirao Y, Miyano T. Interactions between the oocyte and surrounding somatic cells in follicular development: lessons from in vitro culture. J Reprod Dev 2003;49:259-269. [PubMed: 14967918]

3. Abir R, Nitke S, Ben-Haroush A, et al. In vitro maturation of human primordial ovarian follicles: clinical significance, progress in mammals, and methods for growth evaluation. Histol Histopathol 2006;21:887-898. [PubMed: 16691541]

4. Thomas FH, Walters KA, Telfer EE. How to make a good oocyte: an update on in-vitro models to study follicle regulation. Hum Reprod Update 2003;9:541-555. [PubMed: 14714591]

5. Demeestere I, Centner J, Gervy C, et al. Impact of various endocrine and paracrine factors on in vitro culture of preantral follicles in rodents. Reproduction 2005;130:147-156. [PubMed: 16049152]

6. Ksiazkiewicz LK. Recent achievements in in vitro culture and preservation of ovarian follicles in mammals. Reprod Biol 2006;6:3-16. [PubMed: 16604148]

7. Kreeger PK, Deck JW, Woodruff TK, et al. The in vitro regulation of ovarian follicle development using alginate-extracellular matrix gels. Biomaterials 2006;27:714-723. [PubMed: 16076485]

8. Xu M, Kreeger PK, Shea LD, et al. Tissue engineered follicles produce live, fertile offspring. Tissue Eng. 2006In press

9. Xu M, West E, Shea LD, et al. Identification of a stage-specific permissive in vitro culture environment for follicle growth and oocyte development. Biol Reprod 2006;75:916-923. [PubMed: 16957022]

10. Eppig JJ. Mouse oocyte development in vitro with various culture systems. Dev Biol 1977;60:371388. [PubMed: 562802]

11. McGee EA, Hsueh AJ. Initial and cyclic recruitment of ovarian follicles. Endocr Rev 2000;21:200214. [PubMed: 10782364]

12. Irving-Rodgers HF, Rodgers RJ. Extracellular matrix of the developing ovarian follicle. Semin Reprod Med 2006;24:195-203. [PubMed: 16944417]

13. Rodgers RJ, Irving-Rodgers HF, Russell DL. Extracellular matrix of the developing ovarian follicle. Reproduction 2003;126:415-424. [PubMed: 14525524]

14. Irving-Rodgers HF, Rodgers RJ. Extracellular matrix in ovarian follicular development and disease. Cell Tissue Res 2005;322:89-98. [PubMed: 16158327]

15. Rodgers RJ, Irving-Rodgers HF, van Wezel IL. Extracellular matrix in ovarian follicles. Mol Cell Endocrinol 2000;163:73-79. [PubMed: 10963877]

16. Berkholtz CB, Shea LD, Woodruff TK. Extracellular matrix functions in follicle maturation. Semin Reprod Med 2006;24:262-269. [PubMed: 16944423]

17. Albertini DF, Combelles CM, Benecchi E, et al. Cellular basis for paracrine regulation of ovarian follicle development. Reproduction 2001;121:647-653. [PubMed: 11427152]

18. Albertini DF, Fawcett DW, Olds PJ. Morphological variations in gap junctions of ovarian granulosa cells. Tissue Cell 1975;7:389-405. [PubMed: 167472]

19. Anderson E, Albertini DF. Gap junctions between the oocyte and companion follicle cells in the mammalian ovary. J Cell Biol 1976;71:680-686. [PubMed: 825522]

20. Edry I, Sela-Abramovich S, Dekel N. Meiotic arrest of oocytes depends on cell-to-cell communication in the ovarian follicle. Mol Cell Endocrinol 2006;252:102-106. [PubMed: 16647194]

21. Cecconi S, Ciccarelli C, Barberi M, et al. Granulosa cell-oocyte interactions. Eur J Obstet Gynecol Reprod Biol 2004;115(suppl 1):S19-S22. [PubMed: 15196711]

22. Kidder GM, Mhawi AA. Gap junctions and ovarian folliculogenesis. Reproduction 2002;123:613620. [PubMed: 12006089]

23. Plancha CE, Sanfins A, Rodrigues $P$, et al. Cell polarity during folliculogenesis and oogenesis. Reprod Biomed Online 2005;10:478-484. [PubMed: 15901455]

24. Bornslaeger EA, Schultz RM. Regulation of mouse oocyte maturation: effect of elevating cumulus cell cAMP on oocyte cAMP levels. Biol Reprod 1985;33:698-704. [PubMed: 2996645] 
25. Dekel N, Lawrence TS, Gilula NB, et al. Modulation of cell-to-cell communication in the cumulusoocyte complex and the regulation of oocyte maturation by LH. Dev Biol 1981;86:356-362. [PubMed: 6793428]

26. Gilula NB, Epstein ML, Beers WH. Cell-to-cell communication and ovulation. A study of the cumulus-oocyte complex. J Cell Biol 1978;78:58-75. [PubMed: 670298]

27. Martinovitch PN. The development in vitro of the mammalian gonad. Ovary and ovogenesis. Proc R Soc Lond B Biol Sci 1938;125:232-249.

28. O'Brien MJ, Pendola JK, Eppig JJ. A revised protocol for in vitro development of mouse oocytes from primordial follicles dramatically improves their developmental competence. Biol Reprod 2003;68:1682-1686. [PubMed: 12606400]

29. Eppig JJ, O'Brien MJ. Development in vitro of mouse oocytes from primordial follicles. Biol Reprod 1996;54:197-207. [PubMed: 8838017]

30. Cortvrindt R, Smitz J, Van Steirteghem AC. In-vitro maturation, fertilization and embryo development of immature oocytes from early preantral follicles from prepuberal mice in a simplified culture system. Hum Reprod 1996;11:2656-2666. [PubMed: 9021369]

31. Cecconi S, Gualtieri G, Di Bartolomeo A, et al. Evaluation of the effects of extremely low frequency electromagnetic fields on mammalian follicle development. Hum Reprod 2000;15:2319-2325. [PubMed: 11056125]

32. Eppig JJ, Schroeder AC. Capacity of mouse oocytes from preantral follicles to undergo embryogenesis and development to live young after growth, maturation, and fertilization in vitro. Biol Reprod 1989;41:268-276. [PubMed: 2508774]

33. Daniel SA, Armstrong DT, Gore-Langton RE. Growth and development of rat oocytes in vitro. Gamete Res 1989;24:109-121. [PubMed: 2591848]

34. Eppig JJ, Downs SM. The effect of hypoxanthine on mouse oocyte growth and development in vitro: maintenance of meiotic arrest and gonadotropin-induced oocyte maturation. Dev Biol 1987;119:313321. [PubMed: 3100361]

35. Schroeder AC, Schultz RM, Kopf GS, et al. Fetuin inhibits zona pellucida hardening and conversion of ZP2 to ZP2f during spontaneous mouse oocyte maturation in vitro in the absence of serum. Biol Reprod 1990;43:891-897. [PubMed: 1705446]

36. Eppig JJ, Hosoe M, O'Brien MJ, et al. Conditions that affect acquisition of developmental competence by mouse oocytes in vitro: FSH, insulin, glucose and ascorbic acid. Mol Cell Endocrinol 2000;163:109-116. [PubMed: 10963882]

37. Gore-Langton RE, Daniel SA. Follicle-stimulating hormone and estradiol regulate antrum-like reorganization of granulosa cells in rat preantral follicle cultures. Biol Reprod 1990;43:65-72. [PubMed: 2118394]

38. Li R, Phillips DM, Mather JP. Activin promotes ovarian follicle development in vitro. Endocrinology 1995;136:849-856. [PubMed: 7867593]

39. Cain L, Chatterjee S, Collins TJ. In vitro folliculogenesis of rat preantral follicles. Endocrinology 1995;136:3369-3377. [PubMed: 7628372]

40. Eppig JJ, Telfer EE. Isolation and culture of oocytes. Methods Enzymol 1993;225:77-84. [PubMed: 8231884]

41. Gutierrez CG, Ralph JH, Telfer EE, et al. Growth and antrum formation of bovine preantral follicles in long-term culture in vitro. Biol Reprod 2000;62:1322-1328. [PubMed: 10775183]

42. Tambe SS, Nandedkar TD. Steroidogenesis in sheep ovarian antral follicles in culture: time course study and supplementation with a precursor. Steroids 1993;58:379-383. [PubMed: 8212088]

43. Roy SK, Treacy BJ. Isolation and long-term culture of human preantral follicles. Fertil Steril 1993;59:783-790. [PubMed: 8458497]

44. Abir R, Franks S, Mobberley MA, et al. Mechanical isolation and in vitro growth of preantral and small antral human follicles. Fertil Steril 1997;68:682-688. [PubMed: 9341611]

45. Gomes JE, Correia SC, Gouveia-Oliveira A, et al. Three-dimensional environments preserve extracellular matrix compartments of ovarian follicles and increase FSH-dependent growth. Mol Reprod Dev 1999;54:163-172. [PubMed: 10471476]

46. Abir R, Fisch B, Nitke S, et al. Morphological study of fully and partially isolated early human follicles. Fertil Steril 2001;75:141-146. [PubMed: 11163829] 
47. Boland NI, Humpherson PG, Leese HJ, et al. Pattern of lactate production and steroidogenesis during growth and maturation of mouse ovarian follicles in vitro. Biol Reprod 1993;48:798-806. [PubMed: 8485244]

48. Nayudu PL, Osborn SM. Factors influencing the rate of preantral and antral growth of mouse ovarian follicles in vitro. J Reprod Fertil 1992;95:349-362. [PubMed: 1517993]

49. Rowghani NM, Heise MK, McKeel D, et al. Maintenance of morphology and growth of ovarian follicles in suspension culture. Tissue Eng 2004;10:545-552. [PubMed: 15165471]

50. Wycherley G, Downey D, Kane MT, et al. A novel follicle culture system markedly increases follicle volume, cell number and oestradiol secretion. Reproduction 2004;127:669-677. [PubMed: 15175503]

51. Torrance C, Telfer E, Gosden RG. Quantitative study of the development of isolated mouse pre-antral follicles in collagen gel culture. J Reprod Fertil 1989;87:367-374. [PubMed: 2621708]

52. Pangas SA, Saudye H, Shea LD, et al. Novel approach for the three-dimensional culture of granulosa cell-oocyte complexes. Tissue Eng 2003;9:1013-1021. [PubMed: 14633385]

53. Kreeger PK, Fernandes NN, Woodruff TK, et al. Regulation of mouse follicle development by folliclestimulating hormone in a three-dimensional in vitro culture system is dependent on follicle stage and dose. Biol Reprod 2005;73:942-950. [PubMed: 15987824]

54. Langer R, Vacanti JP. Tissue engineering. Science 1993;260:920-926. [PubMed: 8493529]

55. Kim BS, Mooney DJ. Development of biocompatible synthetic extracellular matrices for tissue engineering. Trends Biotechnol 1998;16:224-230. [PubMed: 9621462]

56. Haug A, Larsen B. Quantitative determination of the uronic acid composition of alginates. Acta Chem Scand 1962;16:1908-1918.

57. Haug A, Larsen B, Smidsrod O. Studies of the sequence of uronic acid residues in alginic acid. Acta Chem Scand 1967;21:691-704.

58. Lee KY, Mooney DJ. Hydrogels for tissue engineering. Chem Rev 2001;101:1869-1879. [PubMed: 11710233]

59. Drury JL, Mooney DJ. Hydrogels for tissue engineering: scaffold design variables and applications. Biomaterials 2003;24:4337-4351. [PubMed: 12922147]

60. Kong HJ, Lee KY, Mooney DJ. Decoupling the dependence of rheological/mechanical properties of hydrogels from solids concentration. Polym 2002;43:6239-6246.

61. Kong HJ, Smith MK, Mooney DJ. Designing alginate hydrogels to maintain viability of immobilized cells. Biomaterials 2003;24:4023-4029. [PubMed: 12834597]

62. Bouhadir KH, Hausman DS, Mooney DJ. Synthesis of cross-linked poly(aldehyde guluronate) hydrogels. Polymer 1999;40:3575-3584.

63. Bouhadir KH, Lee KY, Alsberg E, et al. Degradation of partially oxidized alginate and its potential application for tissue engineering. Biotechnol Prog 2001;17:945-950. [PubMed: 11587588]

64. Rowley JA, Madlambayan G, Mooney DJ. Alginate hydrogels as synthetic extracellular matrix materials. Biomaterials 1999;20:45-53. [PubMed: 9916770]

65. Stoichet MS, Li RH, White ML, et al. Stability of hydrogels used in cell encapsulation: An in vitro comparison of alginate and agarose. Biotechnol Bioeng 1996;50:374-381. [PubMed: 18626986]

66. Li RH, Altreuter DH, Gentile FT. Transport characterization of hydrogel matrices for cell encapsulation. Biotechnol Bioeng 1996;50:365-373. [PubMed: 18626985]

67. Rodgers RJ, van Wezel IL, Irving-Rodgers HF, et al. Roles of extracellular matrix in follicular development. J Reprod Fertil Suppl 1999;54:343-352. [PubMed: 10692866]

68. Rodgers RJ. Extracellular matrix in the ovary. Semin Reprod Med 2006;24:193-194.

69. Ricciardelli C, Rodgers RJ. Extracellular matrix of ovarian tumors. Semin Reprod Med 2006;24:270282. [PubMed: 16944424]

70. Monniaux D, Huet-Calderwood C, Bellego FL, et al. Integrins in the ovary. Semin Reprod Med 2006;24:251-261. [PubMed: 16944422]

71. Irving-Rodgers HF, Roger J, Luck MR, et al. Extracellular matrix of the corpus luteum. Semin Reprod Med 2006;24:242-250. [PubMed: 16944421]

72. Curry TE Jr, Smith MF. Impact of extracellular matrix remodeling on ovulation and the folliculoluteal transition. Semin Reprod Med 2006;24:228-241. [PubMed: 16944420] 
73. Russell DL, Salustri A. Extracellular matrix of the cumulusoocyte complex. Semin Reprod Med 2006;24:217-227. [PubMed: 16944419]

74. Lutolf MP, Hubbell JA. Synthetic biomaterials as instructive extracellular microenvironments for morphogenesis in tissue engineering. Nat Biotechnol 2005;23:47-55. [PubMed: 15637621]

75. Shin H, Jo S, Mikos AG. Biomimetic materials for tissue engineering. Biomaterials 2003;24:43534364. [PubMed: 12922148]

76. Silva EA, Mooney DJ. Synthetic extracellular matrices for tissue engineering and regeneration. Curr Top Dev Biol 2004;64:181-205. [PubMed: 15563948]

77. Hubbell JA. Materials as morphogenetic guides in tissue engineering. Curr Opin Biotechnol 2003;14:551-558. [PubMed: 14580588]

78. Liu WF, Chen CS. Engineering biomaterials to control cell function. Materials Today 2005;8:28-35.

79. Discher DE, Janmey P, Wang YL. Tissue cells feel and respond to the stiffness of their substrate. Science 2005;310:1139-1143. [PubMed: 16293750]

80. Brandl F, Sommer F, Goepferich A. Rational design of hydrogels for tissue engineering: Impact of physical factors on cell behavior. Biomaterials 2007;28:134-146. [PubMed: 17011028]

81. Paszek MJ, Weaver VM. The tension mounts: mechanics meets morphogenesis and malignancy. $\mathrm{J}$ Mammary Gland Biol Neoplasia 2004;9:325-342. [PubMed: 15838603]

82. Marti A, Feng Z, Altermatt HJ, et al. Milk accumulation triggers apoptosis of mammary epithelial cells. Eur J Cell Biol 1997;73:158-165. [PubMed: 9208229]

83. Paszek MJ, Zahir N, Johnson KR, et al. Tensional homeostasis and the malignant phenotype. Cancer Cell 2005;8:241-254. [PubMed: 16169468]

84. Oster GF, Murray JD, Harris AK. Mechanical aspects of mesenchymal morphogenesis. J Embryol Exp Morphol 1983;78:83-125. [PubMed: 6663234]

85. Trinkaus, JP. Cells into organs: The forces that shape the embryo. Vol. 2nd ed.. Prentice Hall College Division; Englewood Cliffs, NJ: 1984.

86. Farge E. Mechanical induction of Twist in the Drosophila foregut/stomodeal primordium. Curr Biol 2003;13:1365-1377. [PubMed: 12932320]

87. Ingber DE. Mechanobiology and diseases of mechanotransduction. Ann Med 2003;35:564-577. [PubMed: 14708967]

88. Janmey PA, Weitz DA. Dealing with mechanics: mechanisms of force transduction in cells. Trends Biochem Sci 2004;29:364-370. [PubMed: 15236744]

89. Katsumi A, Orr AW, Tzima E, et al. Integrins in mechanotransduction. J Biol Chem 2004;279:1200112004. [PubMed: 14960578]

90. Davies PF. Flow-mediated endothelial mechanotransduction. Physiol Rev 1995;75:519-560. [PubMed: 7624393]

91. Chen CS, Tan J, Tien J. Mechanotransduction at cell-matrix and cell-cell contacts. Annu Rev Biomed Eng 2004;6:275-302. [PubMed: 15255771]

92. Epstein ND, Davis JS. Sensing stretch is fundamental. Cell 2003;112:147-150. [PubMed: 12553903]

93. Gillespie PG, Walker RG. Molecular basis of mechanosensory transduction. Nature 2001;413:194202. [PubMed: 11557988]

94. Blount P. Molecular mechanisms of mechanosensation: big lessons from small cells. Neuron 2003;37:731-734. [PubMed: 12628164]

95. Torday JS, Rehan VK. Mechanotransduction determines the structure and function of lung and bone: a theoretical model for the pathophysiology of chronic disease. Cell Biochem Biophys 2003;37:235246. [PubMed: 12625629]

96. Alenghat FJ, Ingber DE. Mechanotransduction: all signals point to cytoskeleton, matrix, and integrins. Sci STKE 2002;2002:PE6. [PubMed: 11842240]

97. Hamill OP, Martinac B. Molecular basis of mechanotransduction in living cells. Physiol Rev 2001;81:685-740. [PubMed: 11274342]

98. Gudi SR, Clark CB, Frangos JA. Fluid flow rapidly activates G proteins in human endothelial cells. Involvement of $G$ proteins in mechanochemical signal transduction. Circ Res 1996;79:834-839.

[PubMed: 8831508] 
99. Shyy JY, Chien S. Role of integrins in endothelial mechanosensing of shear stress. Circ Res 2002;91:769-775. [PubMed: 12411390]

100. Dull RO, Tarbell JM, Davies PF. Mechanisms of flow-mediated signal transduction in endothelial cells: kinetics of ATP surface concentrations. J Vasc Res 1992;29:410-419. [PubMed: 1489886]

101. Ali MH, Schumacker PT. Endothelial responses to mechanical stress: where is the mechanosensor? Crit Care Med 2002;30:S198-S206. [PubMed: 12004236]

102. Tschumperlin DJ, Dai G, Maly IV, et al. Mechanotransduction through growth-factor shedding into the extracellular space. Nature 2004;429:83-86. [PubMed: 15103386]

103. Bryant SJ, Chowdhury TT, Lee DA, et al. Crosslinking density influences chondrocyte metabolism in dynamically loaded photocrosslinked poly(ethylene glycol) hydrogels. Ann Biomed Eng 2004;32:407-417. [PubMed: 15095815]

104. Bryant SJ, Durand KL, Anseth KS. Manipulations in hydrogel chemistry control photoencapsulated chondrocyte behavior and their extracellular matrix production. J Biomed Mater Res A 2003;67:1430-1436. [PubMed: 14624532]

105. Bryant SJ, Anseth KS. Hydrogel properties influence ECM production by chondrocytes photoencapsulated in poly(ethylene glycol) hydrogels. J Biomed Mater Res 2002;59:63-72. [PubMed: 11745538]

106. Engler AJ, Sen S, Sweeney HL, et al. Matrix elasticity directs stem cell lineage specification. Cell 2006;126:677-689. [PubMed: 16923388]

107. Ries, LAG.; Percy, CL.; Bunin, BR. Introduction. In: Ries, LAG.; Smith, MA.; Gurney, JG., et al., editors. Cancer Incidence and Survival among Children and Adolescents: United States SEER Program 1975-1995. National Cancer Institute; Bethesda, MD: 1999. p. 1-15.NIH Publication no. 99-4649

108. Blatt J. Pregnancy outcome in long-term survivors of childhood cancer. Med Pediatr Oncol 1999;33:29-33. [PubMed: 10401494]

109. Weintraub M, Gross E, Kadari A, et al. Should ovarian cryopreservation be offered to girls with cancer. Pediatr Blood Cancer 2007;48:4-9. [PubMed: 16830321]

110. Maltaris T, Boehm D, Dittrich R, et al. Reproduction beyond cancer: a message of hope for young women. Gynecol Oncol 2006;103:1109-1121. [PubMed: 16996582]

111. Maltaris T, Seufert R, Fischl F, et al. The effect of cancer treatment on female fertility and strategies for preserving fertility. Eur J Obstet Gynecol Reprod Biol 2007;130:148-155. [PubMed: 16979280]

112. Donnez J, Martinez-Madrid B, Jadoul P, et al. Ovarian tissue cryopreservation and transplantation: a review. Hum Reprod Update 2006;12:519-535. [PubMed: 16849817]

113. Nieman CL, Kazer R, Brannigan RE, et al. Cancer survivors and infertility: a review of a new problem and novel answers. J Support Oncol 2006;4:171-178. [PubMed: 16669459]

114. Meirow D, Levron J, Eldar-Geva T, et al. Pregnancy after transplantation of cryopreserved ovarian tissue in a patient with ovarian failure after chemotherapy. N Engl J Med 2005;353:318-321. [PubMed: 15983020]

115. Donnez J, Dolmans MM, Demylle D, et al. Livebirth after orthotopic transplantation of cryopreserved ovarian tissue. Lancet 2004;364:1405-1410. [PubMed: 15488215]

116. Fabbri R. Cryopreservation of human oocytes and ovarian tissue. Cell Tissue Bank 2006;7:113122. [PubMed: 16732414]

117. Dolmans MM, Michaux N, Camboni A, et al. Evaluation of Liberase, a purified enzyme blend, for the isolation of human primordial and primary ovarian follicles. Hum Reprod 2006;21:413-420. [PubMed: 16199426]

118. The Practice Committee of the American Society for Reproductive Medicine. Ovarian hyperstimulation syndrome. Fertil Steril 2006;86(suppl 5):S178-S183. [PubMed: 17055817]

119. Abir R, Roizman P, Fisch B, et al. Pilot study of isolated early human follicles cultured in collagen gels for 24 hours. Hum Reprod 1999;14:1299-1301. [PubMed: 10325281]

120. Vitt UA, Nayudu PL, Rose UM, et al. Embryonic development after follicle culture is influenced by follicle-stimulating hormone isoelectric point range. Biol Reprod 2001;65:1542-1547. [PubMed: 11673273] 
121. Spears N, Boland NI, Murray AA, et al. Mouse oocytes derived from in vitro grown primary ovarian follicles are fertile. Hum Reprod 1994;9:527-532. [PubMed: 8006146]

122. Heise M, Koepsel R, Russell AJ, et al. Calcium alginate microencapsulation of ovarian follicles impacts FSH delivery and follicle morphology. Reprod Biol Endocrinol 2005;3:47. [PubMed: 16162282] 


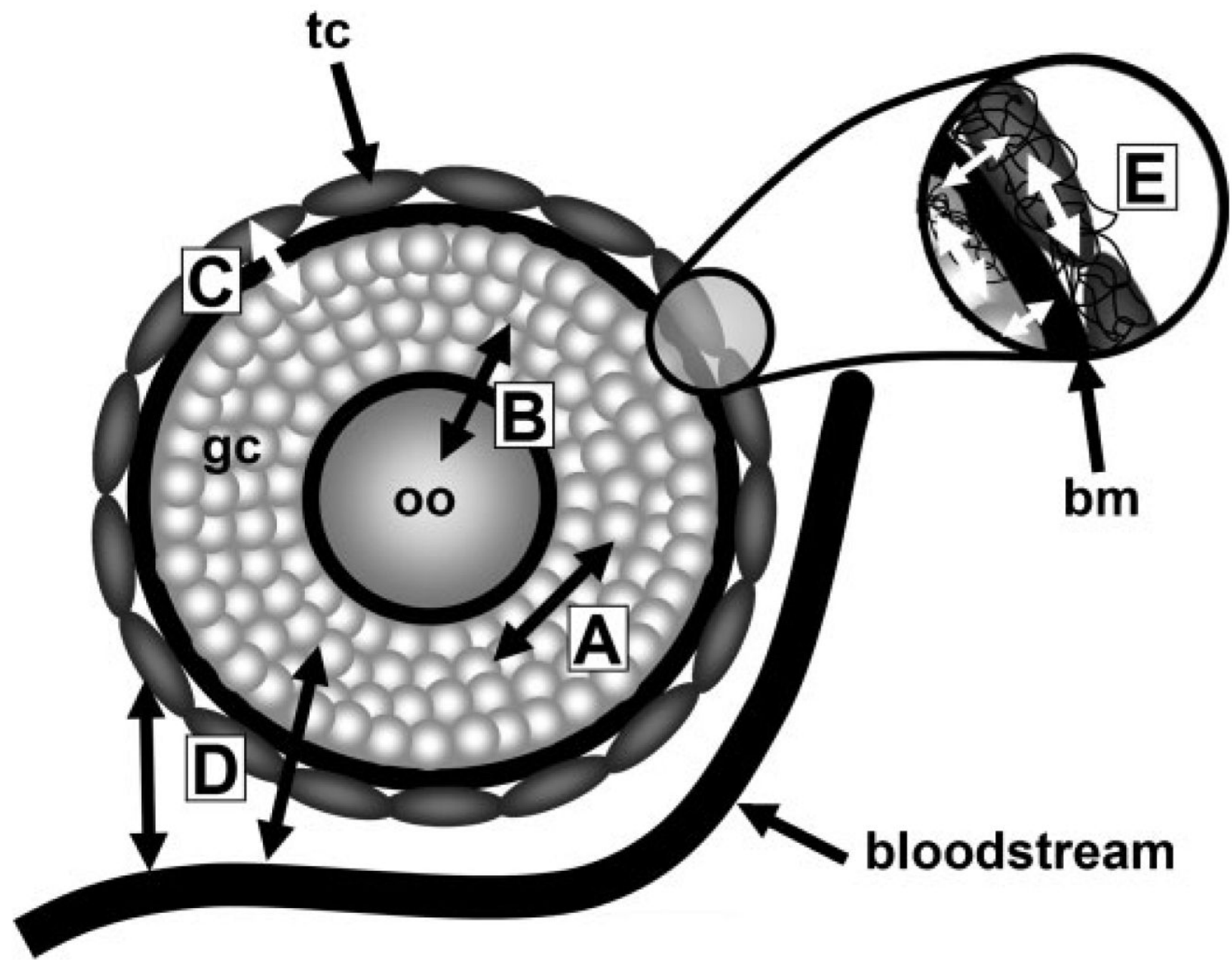

Figure 1.

Follicle development is regulated by (A) interactions between granulosa cells, (B) communication between the oocyte and its surrounding granulosa cells, $(\mathrm{C})$ signaling between the theca and granulosa cells, (D) factors that arrive at the ovary via the bloodstream, and (E) the extracellular matrix within the follicle. oo, oocyte; gc, granulosa cells; tc, theca cells; bm, basement membrane. 

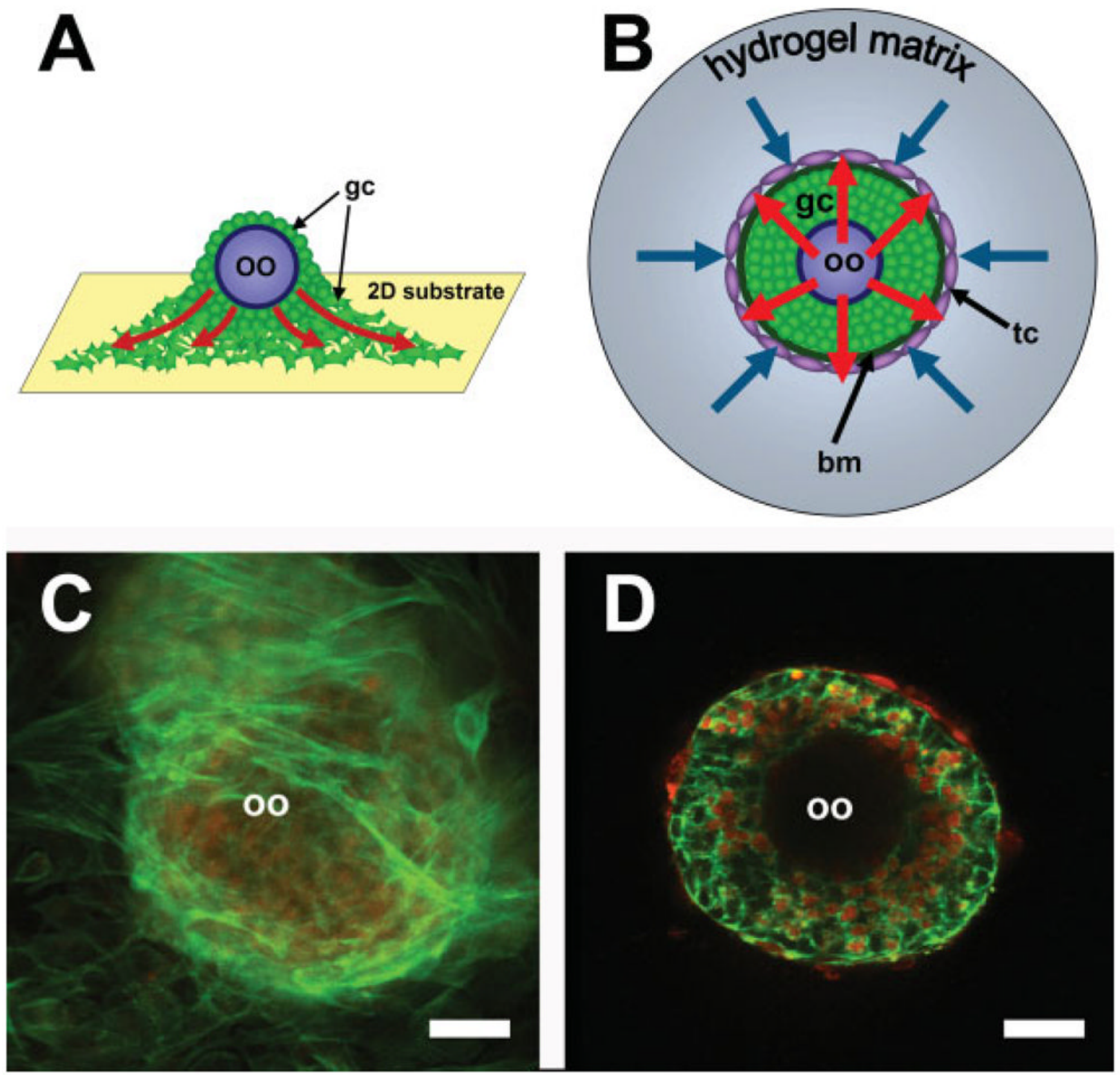

Figure 2.

(A) Follicle architecture in a two-dimensional culture system. On a two-dimensional substrate, proliferating follicle cells spread onto the surface (red arrows). (B) In a three-dimensional culture system, the follicle grows radially from the oocyte (red arrows). If a matrix surrounds the follicle, it will produce an opposing force on the follicle (blue arrows). This is demonstrated in (C) and (D). (C) Follicles cultured on a two-dimensional substrate lose their structure as they spread onto the surface, whereas (D) follicles maintain their morphology in an alginate matrix. Follicles in (C) and (D) are labeled with dextran (red) to demonstrate active uptake of compounds from the culture media and phalloidin (green) to visualize the distribution of the actin cytoskeleton of follicular cells. oo, oocyte; gc, granulosa cells; tc, theca cells. Scale bar $=30 \mu \mathrm{m}$. (Figures 2C and 2D are reprinted from Kreeger, PK, Deck, JW, Woodruff, TK, Shea, 
LD. The in vitro regulation of ovarian follicle development using alginate-extracellular matrix gels. Biomaterials 2006;27:714-723, with permission from Elsevier.) 


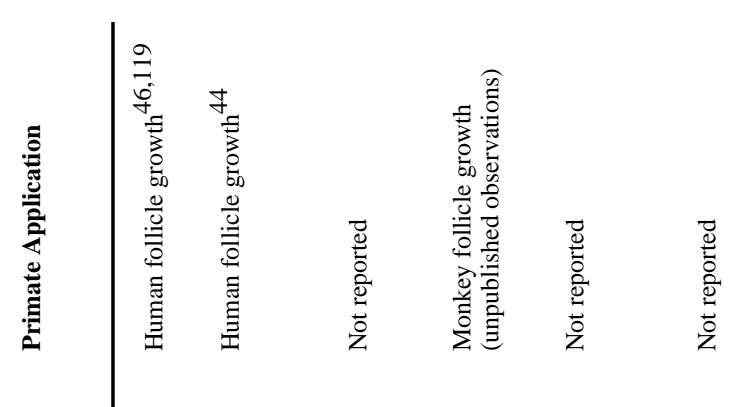

$\frac{0}{\frac{0}{6}}$

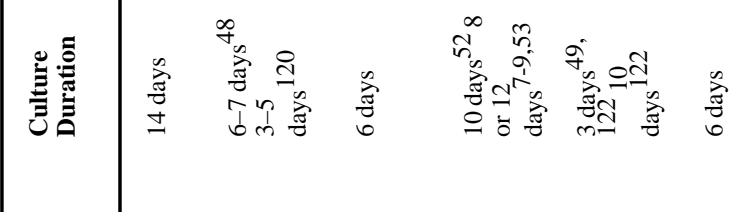

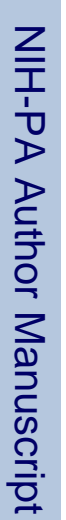

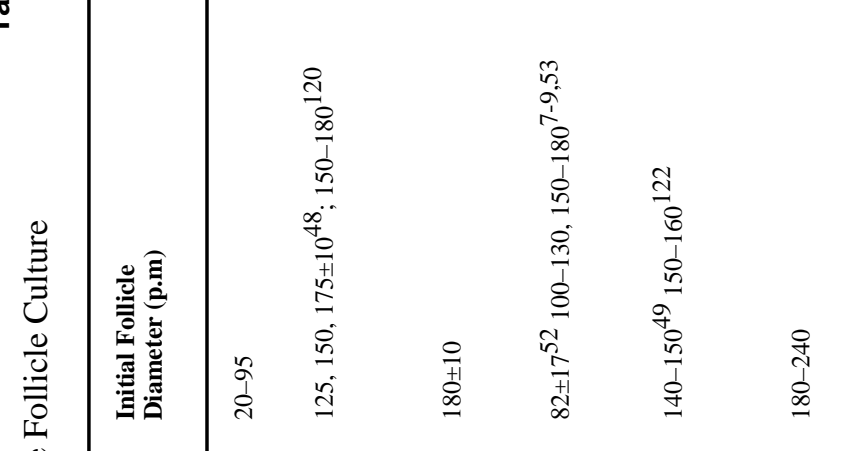

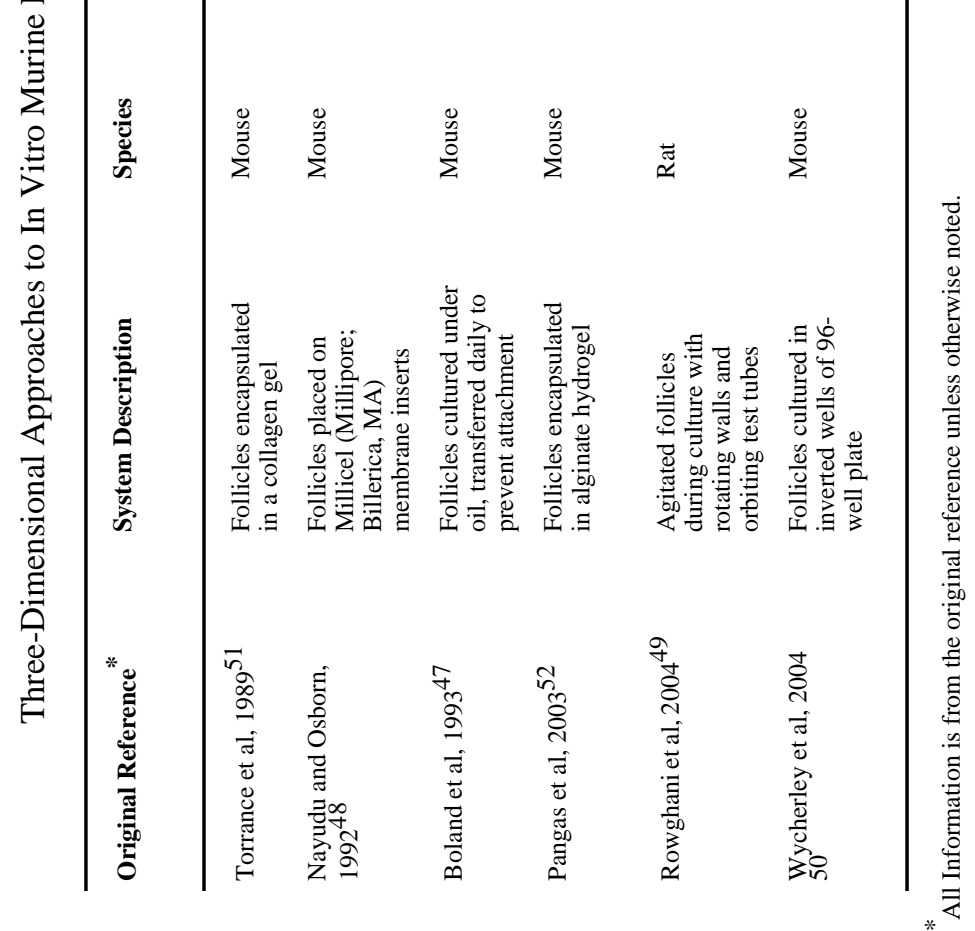


Table 2

Overview of Candidate Tissue Engineering Gels for Use in Follicle Culture

\begin{tabular}{|c|c|c|c|c|}
\hline Material & Origin & Method of Gelation & Method of Digestion & Interactions with Cells \\
\hline Polyethylene glycol (PEG) & Synthetic & $\begin{array}{l}\text { Photocrosslinking, } \\
\text { covalent } \\
\text { crosslinking via } \\
\text { chemical reaction }\end{array}$ & $\begin{array}{l}\text { Dependent on } \\
\text { gelation method, } \\
\text { many methods not } \\
\text { safe for cells }\end{array}$ & None \\
\hline Collagen & Natural (animal) & Temperature & Collagenase & Binds integrins \\
\hline Matrigel & Natural (animal) & Temperature & Collagenase & Binds integrins \\
\hline Agarose & Natural (plant) & Temperature & Agarase & None \\
\hline Alginate & Natural (plant) & $\begin{array}{l}\text { Ionic crosslinking in } \\
\text { presence of divalent } \\
\text { cations (i.e., } \mathrm{Ca}^{2+} \text { ) }\end{array}$ & $\begin{array}{l}\text { Alginate lyase or } \\
\text { EGTA }\end{array}$ & None \\
\hline
\end{tabular}

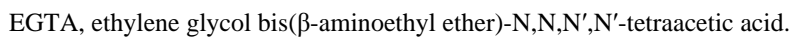

